\title{
ANALISIS VALIDASI MEDIA PEMBELAJARAN E-BOOK BERBASIS FLIP PDF PROFESSIONAL PADA MATERI GELOMBANG BUNYI DI SMA
}

\author{
Tiya Andani*1, Indana Zulfa M², Hadma Yuliani ${ }^{3}$, Nadia Azizah ${ }^{4}$, Rodhatul Jennah ${ }^{5}$ \\ ${ }_{1,2,3,4}$ Program Studi Tadris (Pendidikan) Fisika FTIK Institut Agama Islam Negeri Palangka Raya \\ ${ }^{5}$ Program Studi Pendidikan Islam Anak Usia Dini FTIK Institut Agama Islam Negeri Palangka Raya \\ Jalan George Obos Komplek Islamci Center Palangkaraya \\ e-mail ${ }^{* 1}$ : andanitiya@gmail.com
}

\begin{tabular}{c|c|c}
\hline Diterima 13 Juli 2021 & Disetujui 13 November 2021 & Dipublikasikan 21 Januari 2022 \\
\hline & https://doi.org/10.33369/jkf.4.3.213-220 & \\
\hline
\end{tabular}

\begin{abstract}
ABSTRAK
Penelitian ini dilakukan dengan tujuan untuk menghasilkan media E-book berbasis Flip PDF Professional yang layak digunakan sebagai media pembelajaran pada materi gelombang bunyi kelas XI SMA. Penelitian yang dilakukan merupakan penelitian Research and Development (R\&D) dengan pendekatan 4-D yang meliputi tahap pendefinisian (define), tahap perancangan (design), tahap pengembangan (develop) dan tahap penyebaran (disseminate). Pada penelitian ini hanya dibatasi pada tahap pengembangan saja dikarenakan adanya keterbatasan waktu. Analisis data yang dilakukan pada penelitian ini adalah berdasarkan hasil skor penilaian uji kelayakan media E-book yang telah diberikan oleh validator ahli materi dan validator ahli media. Dari hasil skor penilaian uji kelayakan ahli materi diperoleh hasil sebesar 4,47 dari skor maksimum 5 atau sebesar 83\% dengan kategori sangat layak. Sedangkan hasil skor penilaian uji kelayakan ahli media diperoleh hasil sebesar 4,73 dari skor maksimum 5 atau sebesar $90 \%$ dengan kategori sangat layak. Berdasarkan hasil penelitian ini dapat disimpulkan bahwa media E-book berbasis Flip PDF Professional pada materi gelombang bunyi sangat layak digunakan sebagai salah satu alternatif media pembelajaran.
\end{abstract}

Kata Kunci- Media Pembelajaran, E-Book, Flip PDF Profesional, Gelombang Bunyi

\begin{abstract}
This research was conducted with the aim of producing an E-book based on Flip PDF Professional which is suitable for use as a learning medium for sound wave material for class XI SMA. The research conducted is a Research and Development (R\&D) research with a 4-D approach which includes the definition stage, the design stage, the development stage and the dissemination stage. In this study, it was only limited to the development stage due to time constraints. The data analysis carried out in this study was based on the results of the E-book media feasibility test assessment scores that had been given by material expert validators and media expert validators. From the results of the assessment score of the material expert's feasibility test, the results obtained were 4.47 from a maximum score of 5 or $83 \%$ in the very feasible category. While the results of the assessment score of the media expert's feasibility test obtained a result of 4.73 from a maximum score of 5 or $90 \%$ with a very feasible category. Based on the results of this study, it can be concluded that the E-book media based on Flip PDF Professional on sound wave material is very feasible to be used as an alternative learning media.
\end{abstract}

Keywords - Learning Media, E-Book, Professional PDF Flip, Sound Wave

\section{PENDAhuluan}

Fisika merupakan salah satu mata pelajaran yang diajarkan di sekolah. Pada proses pembelajarannya fisika sering dianggap sebagai salah satu mata pelajaran yang sulit karena memiliki banyak rumus dan konsep didalamnya (1). Selain itu, tujuan dari pelajarannya itu sendiri yang menuntut siswa untuk menguasai konsep yang saling berkaitan dengan rumus-rumus (2). Hal ini sejalan dengan penelitian terdahulu (3) yang mengatakan bahwa pelajaran fisika banyak menerapkan konsep hapalan yang mana dalam hal ini adalah berupa hapalan rumus. Sehingga ini lah yang menyebabkan siswa merasakan bahwa fisika menjadi salah satu mata pelajaran yang sulit dan kurang menarik. Selain itu penelitian yang dilakukan (4) juga mengatakan bahwa permasalahan 
pada bidang studi IPA terletak pada kurangnya pemahaman siswa dalam memahami konsep dan juga kejenuhan yang dirasakan selama proses pembelajaran berlangsung. Oleh karena itu diperlukan suatu media yang dapat membantu siswa dalam memahami pembelajaran.

Pembelajaran fisika dapat di kemas menjadi pembelajaran yang inovatif untuk menyesuaikan perkembangan zaman. Revolusi industri 4.0 ini dapat mempermudah segala informasi untuk dapat diakses kapanpun dan dimanapun seseorang itu berada dan dikemas menjadi lebih praktis. Hal ini sejalan dengan penelitian yang mengatakan bahwa kebanyakan siswa saat ini lebih sering menggunakan gadget dan laptopnya untuk mengakses soft file materi pembelajaran sehingga lebih praktis dan tidak merepotkan (5). Selain itu, juga dikatakan bahwa dengan perkembangan teknologi ini membuat sumber belajar terutama buku teks pelajaran menjadi dapat ditampilkan di alat elektronik dengan tampilan yang sama seperti bentuk aslinya (6). Sehingga dalam hal ini guru sebagai fasilitator dunia pendidikan dituntut untuk dapat lebih terbuka dengan perkembangan dan kecanggihan teknologi ini serta menjadi lebih kreatif dan memberikan fasilitas berupa media pembelajaran yang lebih menarik untuk siswa (7); (8); (2); (9) .

Perkembangan ilmu pengetahuan dan teknologi yang kian hari semakin meningkat memberikan dampak terhadap invoasi yang dihasilkan. Kemajuan teknologi ini banyak dirasakan manfaatnya disegala bidang termasuk dalam bidang pendidikan terutama pada perkembangan bahan ajar (10); (11). Dunia pendidikan dituntut untuk terus maju dan berkembang menyesuiakan perkembangan zaman khususnya dalam hal menciptakan media atau metode pembelajaran fisika yang menarik (3). Media sebagai salah satu sumber belajar harus dapat menampilkan simulasi interaktif berupa video, animasi, audio dan gambar yang mana semuanya ditujukan untuk pemahaman konsep siswa terhadap materi tersebut (12). Media pembelajaran memiliki peran yang sangat penting untuk mencapai suatu tujuan yang telah ditetapkan dalam proses pembelajaran (13); (14).

Media pembelajaran merupakan salah satu alat yang dapat membantu proses pembelajaran dan dipergunakan untuk menyampaikan pesan-pesan atau informasi dalam pembelajaran sehingga memudahkan peserta didik dalam pemahaman materi. Salah satu media pembelajaran yang dapat memberikan kemudahan dari segi pemahaman konsep dan penggunaannya adalah media pembelajaran berbasis elektronik. Hal ini sejalan dengan penelitian (14)yang mengatakan bahwa media elektronik tepat dimanfaatkan untuk media pembelajaran karena dapat membuat peserta didik lebih berminat mengikuti pembelajaran serta dianggap tidak monoton. Salah satu bentuk pembaruan teknologi industry 4.0 dalam pendidikan adalah buku teks pelajaran yang berkembang menjadi buku elektronik (e-book) (12); (15); (16); (17).

E-book adalah sebuah publikasi yang didalamnya memuat teks, gambar, video dan audio yang dipublikasikan dalam bentuk digital dan digunakan dalam perangkat komputer maupun perangkat elektronik lainnya seperti tablet dan android (18); (19). Penggunaan e-book dalam pembelajaran ini memiliki beberapa kelebihan diantaranya lebih praktis, ramah lingkungan, penggunaan yang mudah, simple dan portable (19). Hal ini sejalan dengan penelitian (20) yang mengatakan bahwa keuntungan lainnya dari e-book adalah mengurangi pemakaian kertas secara berlebih sehingga menjadi ramah lingkungan.

Penelitian sebelumnya mengenai bahan ajar elektronik menggunakan Flip PDF Professional pada materi alat-alat optik di SMA memperoleh hasil validasi sebesar 79,45\% dari $100 \%$ dengan kategori sangat valid dan respon sangat baik (10). Karena penelitian sebelumnya belum membahas tentang materi gelombang bunyi maka peneliti tertarik untuk melakukan penelitian dengan materi yang berbeda. Berdasarkan penjelasan diatas, maka peneliti terdorong untuk melakukan penelitian dengan judul "Analisis Validasi Media Pembelajaran E-Book Berbasis Flip PDF Professional pada Materi Gelombang Bunyi di SMA". Adapun tujuan dari penelitian ini adalah untuk mengetahui hasil uji validitas ahli materi dan media terhadap media pembelajaran yang dikembangkan menggunakan aplikasi Flip PDF Professional pada materi gelombang bunyi.

\section{METODE PENELITIAN}

Penelitian ini merupakan penelitian jenis deskriptif dengan pendekatan kualitatif. Penelitian deskriptif merupakan penelitian yang berusaha mendeskripsikan dan menggambarkan fenomena 
yang terjadi secara nyata, faktual sistematis dan akurat (21). Dalam penelitian ini produk yang akan dikembangkan adalah media pembelajaran berupa E-book berbasis aplikasi Flip PDF pada materi gelombang bunyi untuk siswa kelas XI SMA/MA.

Metode yang digunakan pada penelitian ini adalah R\&D (Research and Development) dengan pendekatan penelitian 4-D. Jenis penelitian ini bertujuan untuk menghasilkan suatu media yang bersifat valid dan praktis (22). Selain itu, penelitian ini juga biasanya dilakukan untuk mengembangkan dan memvalidasi suatu program, proses, maupun hasil yang berupa produk khusunya pada bidang pendidikan (16). Thiargarajan (1974) mengemukakan langkah-langkah penelitian 4-D terdiri dari define, design, development, dan dessimination (23).

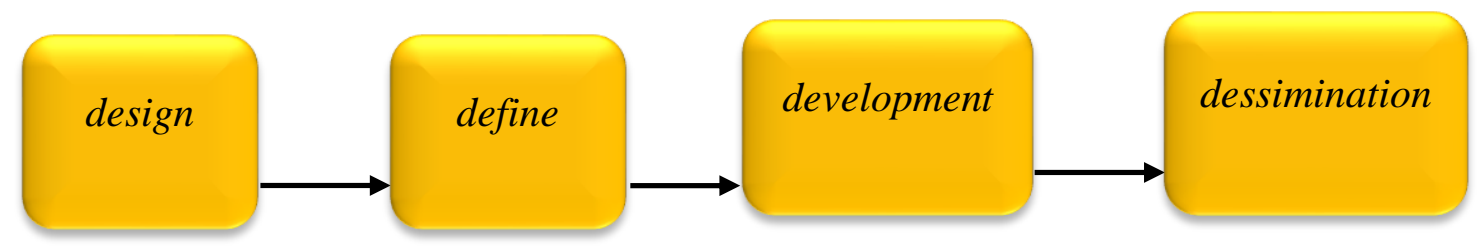

Gambar 1. Skema tahapan penelitian $\mathrm{RnD}$ dengan metode 4-D

Pada tahap define mencakup analisis kebutuhan, masalah serta pengumpulan infromasi dan perumusan tujuan pembelajaran. Pada tahap design meliputi proses perancangan seperti penyusunan instrument, pemilihan media dan rancangan awal media. Pada tahap develop berisi kegiatan pengembangan dan menguji validitas desain, serta revisi desain. Tahap dessimination merupakan tahap penyebar luasan produk (15). Akan tetapi pada penelitian ini hanya dibatasi sampai tahap development saja.

Uji kelayakan yang dilakukan pada produk ini dapat diketahui dengan memberikan sebuah instrument penelitian seperti angket validasi yang ditujukan kepada validator dengan metode pemberian tanda checklist $(\sqrt{ })$ pada kolom penilaian. Kategori kualitatif dapat dilihat pada tabel 1 dibawah ini : (diadaptasi dari (24)).

Tabel 1. Kriteria kelayakan

\begin{tabular}{cc}
\hline Rentang Skor dalam Persen (\%) & Kategori Kualitatif \\
\hline$<21 \%$ & Sangat Tidak Layak \\
$21 \%-40 \%$ & Tidak Layak \\
$41 \%-60 \%$ & Cukup Layak \\
$61 \%-80 \%$ & Layak \\
$81 \%-100 \%$ & Sangat Layak \\
\hline
\end{tabular}

Adapun aspek indikator yang akan di uji kelayakannya adalah sebagi berikut : (diadaptasi dari (24)).

Tabel 2. Indikator aspek penilaian

\begin{tabular}{cc}
\hline Indikator Aspek Penilain Media & Indikator Aspek Penilaian Materi \\
\hline Aspek grafis & Aspek materi \\
Aspek efektivitas & Aspek penyajian \\
Aspek interaktif & Aspek bahasa
\end{tabular}

Aspek tampilan media

Indikator pada aspek grafis terdapat komponen penilaian berupa penyajian $E$-book, pemilihan font, penempatan gambar dan video, kejelasan petunjuk penggunaan E-book, tampilan E-book, penggunaan bahasa serta kemudahan E-book dalam pemahaman peserta didik. Pada aspek efektivitas komponen penilaiannya antara lain sifat E-book dan kemampuan E-book dalam menciptakan motivasi dan rasa senang peserta didik. Pada aspek interaktif komponen penilaiannya berupa penggunaan E-book yang dapat digunakan dalam waktu dan keadaan tertentu serta kemampuan E-book dalam pemahaman konsep materi gelombang bunyi dan membangun pengetahuan peserta didik. Pada aspek tampilan media indikator penilaian mencakup daya dukung media yang meliputi video, audio dan gambar serta navigasi media.

Indikator pada aspek materi terdapat komponen penilaian berupa kesesuaian, kelengkapan dan keakuratan materi, konsep dan definisi, kesesuaian tes formatif dengan indikator pembelajaran, keakuratan notasi dan simbol serta kemudahan dalam memahami materi. Pada aspek penyajian komponen penilaian berupa keruntutan materi dan sajian yang menarik, motivasi dalam 
pengembangan pengetahuan mandiri dan rasa ingin tahu peserta didik, ilustrasi materi (video, audio dan gambar) yang sesuai pada perkembangan peserta didik serta sifat interaktif media. Pada aspek bahasa komponen penilaiannya terdiri dari keterbacaan, ketepatan struktur kalimat, komunikatif serta kejelasan petunjuk dan arahan media.

\section{HASIL DAN PEMBAHASAN}

Media yang dikembangkan pada penelitian ini adalah $E$-Book atau elektronik buku. Media ini dibuat dengan bantuan aplikasi berupa Flip PDF Professional.. Media E-book yang telah selesai selanjutnya dilakukan tahap uji validasi materi dan uji validasi media. Hal ini bertujuan agar mengetahui kelayakan media yang telah dibuat oleh peneliti serta memperbaiki media sesuai saran yang telah diberikan validator.

\subsubsection{Fase Analisis (Analysis)}

Pada tahap ini dilakukan suatu analisis terhadap materi yang akan dibuat media pembelajaran berupa E-book berbasis Flip PDF Proffesional. Berdasarkan hasil analisis, materi gelombang bunyi menjadi pilihan materi yang akan dibuat menjadi media pembelajaran dikarenakan pada materi ini peserta didik masih mengalami kesulitan dan memerlukan suatu media pembelajaran yang membantu dalam pemahamannya.

\subsubsection{Fase Desain (Design)}

Pembuatan media ini melalui beberapa tahapan dimulai dari perancangan media yang dibuat pada Microsoft Word, kemudian menambahkan berbagai media seperti gambar, video, audio dan sebagainya sesuai dengan kebutuhan pada media tersebut. Selanjutnya melakukan perubahan format file dari format $d o c$. menjadi format $p d f$ serta memasukkan media tersebut kedalam aplikasi Flip PDF Professional untuk dilakukan proses perkembangan lebih lanjut. Media E-book berbasis Flip PDF Proffesional ini memuat beberapa komponen pendukung seperti adanya video, animasi, audio yang disusun sedemikian rupa agar dapat memudahkan peserta didik dalam menyusun konsep dan memahami materi yang disajikan. Media ini juga memuat contoh soal dan latihan disetiap pembahasannya. Penyusunan media E-book berbasis Flip PDF Professional dapat dilihat pada gambar 2 dibawah ini :

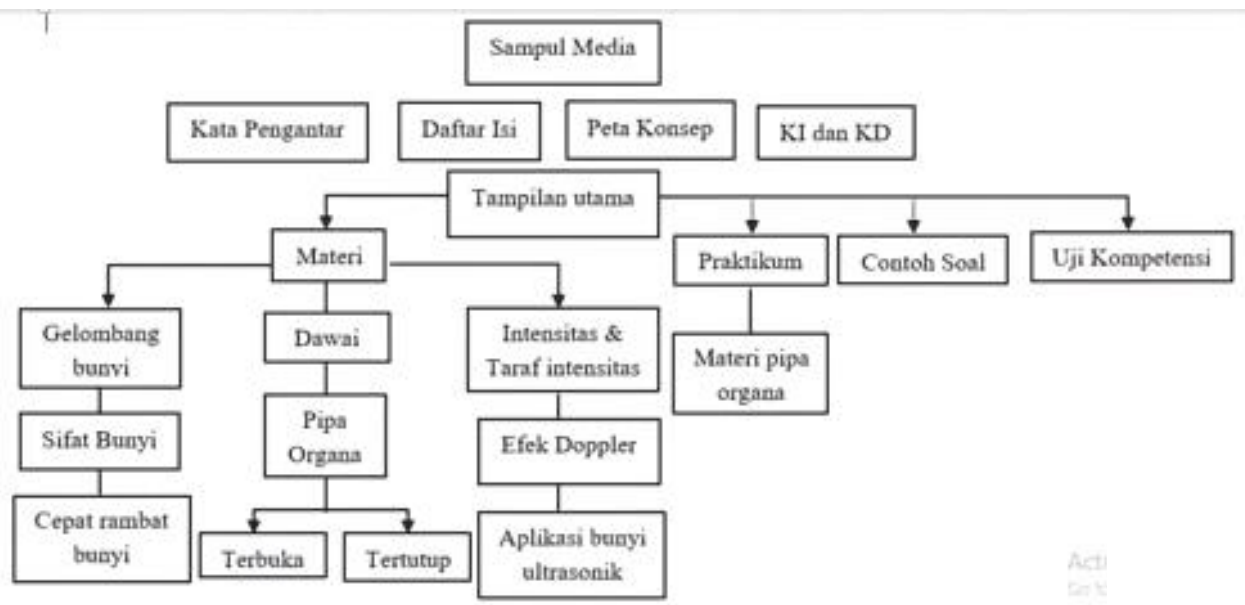

Gambar 2. Historyboard E-book Berbasis Flip PDFProfessional

Pada gambar 2 terlihat bahwa media ini tersusun dari beberapa pembahasan yang terdapat dalam materi gelombang bunyi. Pada tampilan awalnya terdapat sampul media yang memuat judul materi. Kemudian terdapat kata pengantar, daftar isi untuk mempermudah pencarian halaman yang ingin dituju, dan peta konsep sebagai gambaran dari materi yang akan dibahas di dalamnya. Media ini juga memuat latihan soal beserta uji kemampuan peserta didik terhadap materi yang telah dipelajari atau uji kompetensi.

\subsubsection{Fase Pengembangan (Development)}

Rancangan yang telah dibuat sebelumnya kemudian dikembangkan hingga menjadi sebuah produk berupa E-book berbasis Flip PDF Professional. Media ini dapat dilihat pada gambar 3 dibawah ini : 


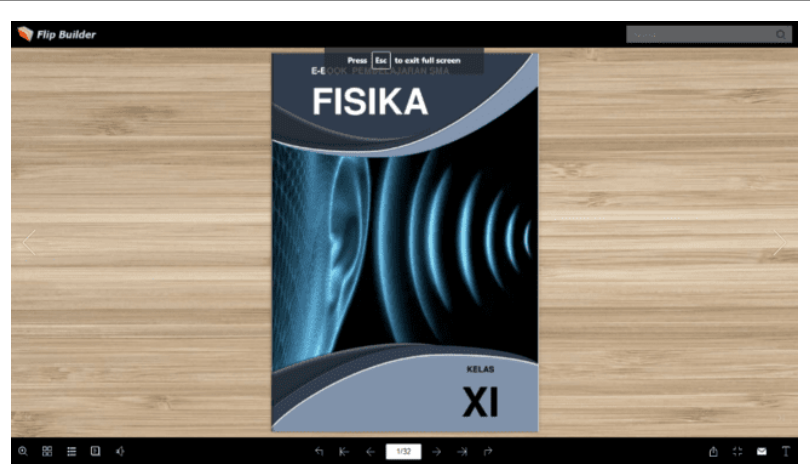

Gambar 3. Tampilan sampul media E-Book

Gambar 3 merupakan tampilan sampul utama dari media yang telah dibuat. Penggunaan media ini menggunakan tombol navigasi yang terletak pada bagian bawah sampul atau bagian kanan dan kiri sampul. Pengguna dapat menekan tombol navigasi tersebut dan dapat langsung berpindah ke halaman selanjutnya ataupun sebelumnya dari awal hingga akhir. Tombol navigasi pada media ini hanya dapat diloncat langsung ke halaman sampul awal dan sampul akhir saja. Ketika memindahkan halaman pada media ini pengguna akan merasa seperti membuka lembaran buku yang nyata.

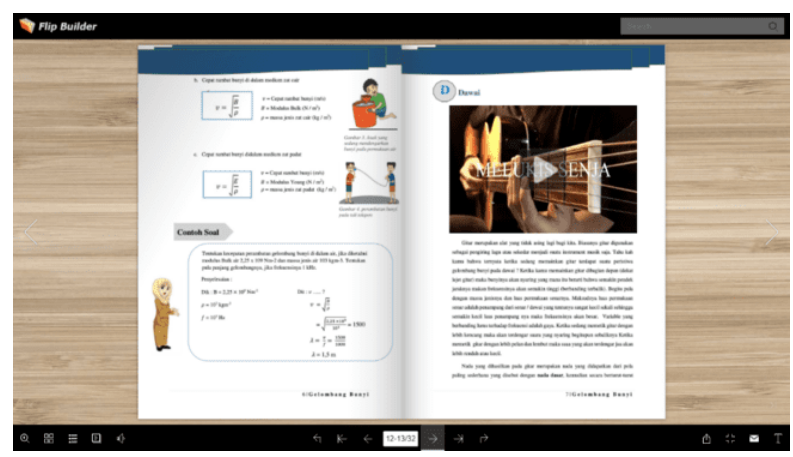

Gambar 4. Tampilan isi dalam media E-Book

Gambar 4 merupakan tampilan isi dalam media E-book di salah satu halaman. Media ini memuat materi dan juga contoh latihan dalam setiap pembahasannya. Hal ini dibuat agar peserta didik dapat lebih memahami setiap pembahasan yang telah dipelajari. Media ini juga memuat animasi yang bisa digunakan sebagai contoh nyata dalam penjelasan teori sebelumnya. Selain itu, dapat dilihat pada gambar 4 terdapat video yang berkaitan dengan materi yang akan dibahas. Video ini bersifat offline sehingga tanpa menggunakan jaringan internet pengguna tetap bisa menutar video tersebut. Ketika video diputar pengguna dapat menghentikannya (Pause) sebelum video berakhir dan juga dapat dibesarkan ukurannya hingga memenuhi layar perangkat yang digunakan sehingga memberikan kenyamanan dalam penggunaannya.

3.1.4 Fase Implementasi (Implementation)

Setelah selesai tahap pembuatan produk selanjutnya media E-book ini dilakukan uji validasi untuk melihat kelayakan media yang telah dibuat oleh beberapa pakar atau ahli baik ahli materi maupun ahli media. Validator media ini terdiri dari 4 orang yang terdiri dari 2 validator ahli materi dan 2 validator ahli media. Hasil yang didapatkan dari validator dapat dilihat pada tabel 3 dibawah ini.

Tabel 3. Hasil rekapitulasi uji kelayakan ahli materi dan media

\begin{tabular}{llccc}
\hline \multirow{2}{*}{ Aspek } & \multirow{2}{*}{ Indikator aspek penilaian } & \multicolumn{2}{c}{ persentasi } & \multirow{2}{*}{ kategori } \\
\cline { 3 - 4 } & & Validator A & Validator B & \\
& Aspek grafis & $97 \%$ & $82 \%$ & \\
\multirow{2}{*}{ Media } & Aspek efektivitas & $100 \%$ & $73 \%$ & Sangat \\
& Aspek interaktif & $100 \%$ & $100 \%$ & layak \\
& Aspek tampilan media & $100 \%$ & $90 \%$ & \\
\multirow{2}{*}{ Materi } & Aspek materi & $97 \%$ & $68 \%$ & Sangat \\
& Aspek penyajian & $68 \%$ & $80 \%$ & layak \\
\hline
\end{tabular}




\begin{tabular}{|c|c|c|c|c|}
\hline \multirow{2}{*}{ Aspek } & \multirow{2}{*}{ Indikator aspek penilaian } & \multicolumn{2}{|c|}{ persentasi } & \multirow{2}{*}{ kategori } \\
\hline & & Validator A & Validator B & \\
\hline
\end{tabular}

Nilai hasil validasi aspek media yang meliputi aspek grafis, aspek efektivitas, aspek interaktif, dan aspek tampilan media secara keseluruhan memiliki kategori sangat layak. Hal ini dikarenakan media E-book berbasis Flip PDF Professional memiliki tampilan yang menarik dengan daya dukung video dan audio yang sesuai. Pendapat ini sejalan dengan penelitian (11) yang mengatakan bahwa flipbook berbasis literasi islam yang diuji cobakan menarik dalam semua aspek salah satunya tampilan media dan kesesuaian gambar, animasi, audio, video dan simulasi. Selain itu media ini dapat memberikan kemudahan bagi peserta didik dalam pemahaman materi dan konsep serta dapat menciptakan motivasi dan keaktifan peserta didik dalam membangun pengetahuannya sendiri. Hal ini sejalan dengan penelitian (25). Penggunaan media E-book berbasis Flip PDF Professional dapat diakses diberbagai tempat, waktu dan keadaan.

Adapun nilai hasil validasi aspek materi yang meliputi aspek materi, aspek penyajian dan aspek bahasa memiliki kategori sangat layak. Hal ini dikarenakan media E-book berbasis Flip PDF Professional memuat materi yang menarik dan runtut dalam penyajiannya serta sesuai dengan perkembangan peserta didik. Selain itu bahasa $E$-book yang dibuat juga bersifat komunikatif dan jelas dalam petunjuk penggunaannya. Hal ini sejalan dengan penelitian (5) yang mengatakan bahwa bahasa yang digunakan E-book bersifat komunikatif serta tidak menimbulkan penafsiran yang berbeda oleh peserta didik sehingga dapat membantu memahami materi yang ada. Berdasarkan dua kategori pada aspek media dan aspek materi tersebut maka dapat disimpulkan bahwa media ini dapat digunakan sebagai salah satu alternatif media pembelajaran.

Dalam validasi ini terdapat beberapa perbaikian dari validator yang dapat dilihat pada tabel 4 dibawah ini.

Tabel 4. Aspek yang direvisi

\begin{tabular}{ll}
\hline No & \multicolumn{1}{c}{ Saran perbaikan } \\
\hline 1 & Memperbaiki format (spacing) \\
2 & Memberikan penjelasan medium yang paling cepat merambatkan bunyi \\
3 & Memberikan penjelasan ultrasonik dan infrasonik \\
4 & Memberikan penjelasan perambatan energi gelombang bunyi \\
5 & Judul sub bab yang dibikin lebih ringkas \\
6 & Menambahkan indikator cepat rambat bunyi \\
7 & Menambahkan hubungan persamaan cepat rambat bunyi dan periode \\
8 & Memberikan pertanyaan pada kegiatan praktikum pipa organa \\
9 & Memperjelas konsep efek doopler \\
10 & Menambahkan pertanyaan tentang penerapan bunyi dalam teknologi \\
11 & Mengubah penggunaan kata yang keliru diawal paragraf \\
12 & Memperbaiki kesalahan penulisan (Typo)
\end{tabular}

Berdasarkan saran perbaikan yang diberikan oleh validator ahli dan validator media, selanjutnya dilakukan perbaikan secara keseluruhan. Adapun masukan yang diberikan validator pada aspek grafis adalah penyajian E-book harus mempresentasikan kosep dan materi secara lengkap serta indikator yang harus termuat seluruhnya dalam materi. Pada aspek materi masukan yang diberikan yaitu kegiatan parktikum perlu ditambahkan pertanyaan untuk mengetahui kemampuan peserta didik dalam menganalisis hasil data percobaannya serta tes formatif yang disajikan harus memuat semua indikator yang telah dibuat. Selain itu masukan yang diberikan oleh validator pada aspek bahasa berkaitan dengan pengguaan kata diawal kalimat yang harus sesuai dengan struktur kalimat yang benar. Hal ini dikarenakan pada media pembelajaran diperlukan peletakan tata bahasa yang tepat. Pendapat ini sesuai dengan penelitian (26) yang mengatakan bahwa kelayakan pada kriteria bahasa media harus dapat mencakup kriteria tata bahasa Indonesia atau EYD yang benar.

Berdasarkan saran-saran yang diberikan oleh validator selanjutnya peneliti melakukan tahap perbaikan sesuai masukan. Hasil rekapitulasi uji kelayakan ahli media dan ahli materi maka 
diperoleh hasil kelayakan media sebesar $90 \%$ dan kelayakan materi sebesar 83\% dengan kategori sangat layak. Hal ini sejalan dengan penelitian (27) yang mengatakan bahwa hasil rekapitulasi $E$ book metabolisme protein berbasis Flip PDF Professional ahli materi dengan kategori baik, ahli bahasa kategori sangat baik dan ahli media dengan kategori sangat layak. Sehingga dapat diberi kesimpulan bahwa media yang dikembangkan yaitu E-book berbasis Flip PDF Professional pada materi gelombang bunyi dapat digunakan sebagai salah satu alternatif media pembelajaran.

\section{SIMPULAN DAN SARAN}

\subsection{Simpulan}

Berdasarkan hasil rekapitulasi uji kelayakan validasi ahli materi dan ahli media serta pembahasan yang dilakukan maka diperoleh hasil rekapituasi uji kelayakan E-book oleh ahli media yang ditinjau dari aspek grafis, aspek efektivitas, aspek interaktif dan aspek tampilan media memperoleh persentase sebesar 90\% dengan kategori sangat layak. Sedangkan hasil rekapitulasi uji kelayakan E-book oleh ahli materi yang ditinjau dari aspek materi, aspek penyajian dan aspek bahasa diperoleh persentase sebesar $83 \%$ dengan kategori sangat layak. sehingga dapat disimpulkan bahwa media pembelajaran E-book berbasis Flip PDF Proffesional pada materi gelombang bunyi di SMA layak digunakan sebagai salah satu alternatif media pembelajaran dengan kriteria sangat layak.

\subsection{Saran}

Saran yang dapat dikemukakan berdasarkan hasil penelitian ini yaitu perlu adanya media pembelajaran yang lebih menarik minat peserta didik dalam belajar dengan memperhatikan indikator pencapaian dan kejelasan materi yang akan dibahas serta penulisan tata bahasa yang harus diperhatikan sesuai dengan pedoman tata bahasa Indonesia

\section{UCAPAN TERIMA KASIH}

Penulis mengucapkan terimakasih yang sebesarnya kepada responden guru dan peserta didik di SMAN 2 Sampit yang telah bersedia mengisi angket analisi kebutuhan yang disebarkan melalui link google form.

\section{DAFTAR PUSTAKA}

1. Hadi W. Pengembangan Komik Fisika Berbasis Android Sebagai Suplemen Pokok Bahasab Radioaktivitas Untuk Sekolah Menengah Atas. 2015.

2. Goal ML, Serevina V, Supriyati Y. Media Pembelajaran Ebook Berbasis 3d Pageflip Pada Materi Suhu Dan Kalor Dengan Model Pembelajarn Discovery Learning. In: Prosiding Seminar Nasional Fisika (E-Journal). 2019. p. VIII.

3. Humairoh F, Wasis. Pengembangan E-Book Interaktif Berbasis Salingtemas (Sains, Lingkungan, Teknologi, Masyarakat) pada Materi Fluida Dinamis untuk Meningkatkan Pemahaman Konsep Siswa dan Penerapannya. J Inov Pendidik Fis (JIPF. 2015;04(02).

4. Mulyadi DU, Wahyuni S, Handayani RD. Pengembangan media flash flipbook untuk meningkatkan keterampilan berpikir kreatif siswa dalam pembelajaran IPA di SMP. J Pembelajaran Fis. 2016;4(4):296-301.

5. Pramana WD, Dewi NR. Pengembangan E-Bookipa Terpadu Tema Suhu Dan Pengukuran Untuk Menumbuhkan Kemandirianbelajar Siswa. Unnes Sci Educ J. 2014;3(3).

6. Simangunsong YP, Muchta YR, Utami IS. Pengembangan Media Flipbook Fisika Berbasis Model Pembelajaran Inkuiri Terbimbing Pada Materi Gerak Harmonik Sederhana Untuk Siswa Sma Kelas X. In: Prosiding Seminar Nasional Pendidikan Fisika. 2020.

7. Ayu F, Fauzi A. Praktikalitas Pengembangan E-Book Fisika Berbantuan Edmodo Berbasis Discovery Learning Dalam Proses Pembelajaran Fisika. J Inov Pendidik dan Sains. 2020;1(3):66-71.

8. Cahyanti R, Akhlis I. Pengembangan E-Book Sebagai Implementasi Model Pembelajaran 
Inkuiri Terbimbing Materi Mesin Atwood Untuk Siswa Sma N 1 Kradenan. Unnes Phys Educ J. 2015;4(1).

9. Musdalifa H, Khaeruddin. Pengembangan E-Bookuntuk Meningkatkan Motivasi Dan Hasil Belajar Ipa Fisika Di Smp Satap Negeri 8 Sengkang. Universitas Negeri Makassar; 2021.

10. Wilujeng I, Mulyaningsih S. Pengembangan Media E-Bookinteraktif Melalui Strategi Mind Mapping Pada Materi Pokok Listrik Dinamis Untuk Sma Kelas X. J Inov Pendidik Fis. 2013;02(02):55-61.

11. Diani R, Hartati NS. Flipbook berbasis literasi Islam: Pengembangan media pembelajaran fisika dengan 3D pageflip professional. J Inov Pendidik IPA. 2018;4(2):234-244.

12. Wijayanti K, M. Pengembangan E-bookIPA Fisika Berbasis Program Sigil Peserta Didik SMPN 23 Simbang Kabupaten Maros. In: Seminar Nasional Fisika. 2018.

13. Hidayat A, Suyatna A, Suana W. Pengembangan Buku Elektronik Interaktif Pada Materi Fisika Kuantum Kelas Xii Sma. J Pendidik Fis. 2017;V(2):87-101.

14. Fauzi A. Pengembangan Media Pembelajaran E-Book Pada Materi Jenis Dan Karakteristik Bahan Baja Kelas X Tgb Smk Negeri 1 Mojokerto. Pendidik Tek Bangunan. 2015;1(1):148151.

15. Suprapto E, Apriandi D, Pamungkas IP. Pengembangan E-Book Interaktif Berbasis Animasi Bagi Siswa Sekolah Menengah Kejuruan. ANARGYA J Ilm Pendidik Mat. 2019;2(2):124130.

16. Putri GE, Ayu F, Fauzi A. ValiditasE-BookFisika Terintegrasi Materi Bencana PetirBerbasis Model Pembelajaran Penemuan. JPF( J Eksakta Pendidik. 2020;4(2):163-170.

17. Sumantri FN, Kholiq A. Pengembanganels-3d (E-Bookliterasi Sains Berbasis 3d Page Flip) Pada Materi Momentum Dan Impuls. IPF Inov Pendidik Fis. 2020;09(03):479-483.

18. Andikaningrum L, Damayanti W, Dewi C. Efektivitas E-Book Berbasis Multimedia Menggunakan Flip Book Maker Sebagai Media Pembelajaran dalam Meningkatkan Keaktifan Belajar SIswa (Studi Kasusu pada Mata Pelajaran TIK Kelas XI SMA Kristen Satya Wacana Salatiga). 2014.

19. Wardani R, Hariyanto D, Subhan A. Laporan Program Penyusunan Naskah Kajian: Pengembangan Interaktif E-Book dari Sisi Pedagogik, Teknologi Perangkat Lunak Serta Media yang Digunakan. 2012.

20. Simanjuntak ST, Supriyati Y, Fahdiran R. Pengembangan Buku Elektronik Pengayaan Pengetahuan Tentang Aplikasi Gelombang Ultrasonik Untuk Siswa Sma. In: Prosiding Seminar Nasional Fisika (E-Journal) SNF2019. 2019.

21. Rukajat A. Pendekatan Penelitian Kuantitatif: Quantitative Research Approach. Sleman: Deepublish; 2018.

22. Setiyo E, Zulhermanan, Harlin. Pengembangan Media Pembelajaran Berbasis Flash Flip BookpadaMataKuliah Elemen Mesin 1di Program Studi Pendidikan Teknik MesinUniversitas Sriwijaya. INVOTEK J Inov Vakosional dan Teknol. 2018;18(1):1-6.

23. Sugiyono P. Metode Penelitian Pendidikan Penelitian Kuantitatif. Bandung: Alfabeta CV; 2010.

24. Arikunto S. Evaluasi Program Pendidikan. Jakarta: Bumi Aksara; 2010.

25. Parlin ID, Iswanto BH, Budi AS. Pengembangan Media Pembelajaran Berbasis Kvisoft untuk Meningkatkan Pemahaman Konsep Peserta Didik pada Materi Medan Magnet. In: Prosiding Seminar Nasional Fisika (E-Journal) SNF 2015, IV. 2015. p. 135-140.

26. Kurniawan H, Suprapto N. Pengembangan Media Pembelajaran Multimedia Flash Ineraktif pada Materi Listrik Dinamis Kelas XII di SMAN 1 Krain. J Inov Pendidik Fis (JIPF. 2014;16-19.

27. Susanti T, Kurniadewi F, Nurjayadi M. Development of Protein Metabolism Electronic Module by flip PDF PRofessional Applicatioj. J Phys. 2021;1-7. 